European Journal of Business and Innovation Research

Vol.8, No.4.pp. 50-62, July 2020

Published by ECRTD-UK

Print ISSN: 2053-4019(Print), Online ISSN: 2053-4027(Online)

\title{
ETHICAL RESPONSIBILITIES AND THE PERFORMANCE OF MANUFACTURING FIRMS IN NIGERIA
}

\author{
Enuoh, Rebecca Oliver, Okoh, Josephine Queen, Iheanacho MaryJoan Ugboaku \\ Ekpe Ekpe Oyono, Pepple, Grace Jamie
}

Faculty of Management Sciences

Department of Business Management, University of Calabar,

\begin{abstract}
Corporate social responsibility $(C S R)$ is a public relations concept geared towards actualizing the objective of maintaining favorable environment for the community within which the organization exists and from where it derives its sustenance. The sphere of responsibilities by corporate bodies cut across economic, legal, ethical and philanthropic dimensions. This study focused on ethical responsibilities and the performance of manufacturing firms in Nigeria using Lafarge Cement Company as case study. The major objective of the research was to examine how ethical considerations are adhered to in the operations of manufacturing firms. The research also aimed to ascertain the resultant effect of corporate expenditure in creating a conducive and friendly business environment. The study used ex-post facto research design to obtain secondary data from the financial report of the company. Multiple regression analyses were used to find the relationship between variables and their significance. The findings revealed that waste management cost does not significantly affect financial performance of the company. The result of the study showed that CSR affects the financial performance when viewed holistically. However, the chosen variables show no significant effect.
\end{abstract}

KEYWORDS: corporate social responsibility, ethical responsibility. Performance, manufacturing firm

\section{INTRODUCTION}

The field of corporate social responsibility (CSR) has grown exponentially in the last decade. A large number of companies are engaged in serious efforts to define and interpret CSR into all aspects of their business. An increasing number of shareholders, analyst, regulators, activist labor unions, employees, community, organization and new media are asking to be accountable for an ever- changing set of CSR issues. Each company differs in how it implements CSR if at all. The differences depend on such factors as the specific company's size, the particular industry involved, the firm's business culture, stake holder' demands and how historically progressive the company is in engaging in CSR.

Some companies focus on single area which is regarded as the most important for them or where they have the highest impact or vulnerability human right, for example or the environment. While others aim to integrate CSR in all aspects of their operations for successful implementation, it is crucial that the CSR principle is part of the corporation's values and strategic planning and that both management and employees are committed to them. Manufacturing firm also perform their 
European Journal of Business and Innovation Research

Vol.8, No.4.pp. 50-62, July 2020

Published by ECRTD-UK

Print ISSN: 2053-4019(Print), Online ISSN: 2053-4027(Online)

own CSR to the host community in which they are located. Its social responsibility extends to customers, government and other stakeholders. Such CSR could be in form of free housing, good health care, infrastructure and scholarships. These are all aimed at creating a stable balance between its profitability and the environment in which they operate (Azende, 2013). However, it is still uncertain as to whose interest such CSR activities are meant to protect (Enuoh \& Eneh 2015).

The development, protection and enhancement to support the improvement of the society's income as well as the reduction of economic and social inequality problems is not entirely solved taking the aforesaid need into consideration, there is reason to conceptualize CSR from the perspective of manufacturing firms in Nigeria. It is clear from the undergoing that CSR as a public relations concept is geared towards actualizing the objective of maintaining a conducive environment for the community within which the organization exists and from where it derives its sustenance. Manufacturing firms can be the main stay of an economy particularly in terms of employment and livelihood of the people.

Most manufacturing firms are engulfed in problems of waste disposal of residues after production. If this is not properly done, it makes the environment unfit and harmful for business operations. CSR is also displayed in community relations activities done by firm such as career training, health programmes, sponsor of cultural events and others, for which resources are expended for carrying out such activities and at a whole affecting the profitability of the firm. However, firms that fail to engage in CSR activities alienate themselves from the society in which they operate creating an uncomfortable environment for business. This could affect their revenue base and adversely impacts on profit of the entity. It is also ethically required for companies to be responsible for the environment in which they operate (Enuoh, 2019), regardless of the impact on their profit. Based on this premise, this study intends to examine the effect of ethical responsibilities on performance of manufacturing firms. The other objective is to examine the impact of waste disposal methods on the profitability of manufacturing firms..

\section{The concept of Corporate Social Responsibility}

The definition of Corporate Social Responsibility lacks universality, and different interpretations have been given to it (Dutta \& Bose, 2008). It is a multifarious concept that lends itself to multiplicity of meanings. However, for the purposes of this study, CSR is described as a collection of activities which are of direct benefit to society that a firm voluntarily or discretionally undertakes. These activities form part of the overall corporate responsibilities that the firm owes its stakeholders and the natural environment within its scope of operations (Waddock, 2006). They are designed to create some positive impact on the firm's environment and its stakeholders.

Through CSR, businesses reaffirm their principles and values, both in their processes and operations and in their interaction with other social actors. CSR is generally voluntary in nature and refers to activities that exceed a mere compliance with the law. The social and environmental responsibilities of enterprises may reflect the changing expectations of society. For example, what enterprises consider convenient practices today may become indispensable ones tomorrow? In addition, it is expected that different social actors interested in the activities of a certain enterprise 
European Journal of Business and Innovation Research

Vol.8, No.4.pp. 50-62, July 2020

Published by ECRTD-UK

Print ISSN: 2053-4019(Print), Online ISSN: 2053-4027(Online)

will prioritize different social and environmental demands, which may contradict or compete with one another at times.

Corporate social responsibility poses several challenges for enterprises, including the need to define their responsibilities with respect to those of the public sector, determine the extent of their obligations in the supply chain and decide what point in the future they should anticipate and plan for the consequences of their activities, especially in the case of natural resource use. Pragmatism in CSR is essential because despite the many issues it can address, CSR also has its limits and cannot substitute for the role of government in enforcing laws and international labour standards. CSR as defined by European Commission (2001) is an idea whereby companies integrate social and environmental concerns in their business operations and in their interface with their stakeholders on a voluntary basis acknowledging that responsible behaviour leads to sustainable business success. CSR social activities may include charitable contributions to local and national organizations such as fundraising, donations and gifts in areas where it trades and others like regeneration of deprived communities, reclamation of derelict land and creation of new regeneration jobs.

However, what cuts across a number of definitions that scholars have proposed on the concept of CSR is the general belief that, beyond the quest to maximize corporate profits, corporate organizations play a crucial role in solving society's problems. For Comincioli, Poddi, \& Vergalli (2012), the fundamental idea of CSR is that it reflects both the social imperatives and the social consequences of business success, and that responsibility accordingly falls upon the corporation, but the precise manifestation and direction of the responsibility lies at the discretion of the corporation. Such a characterization of CSR makes it a mandatory exercise aimed at solving society's problems. We argue that, though the modalities of implementing CSR programmes are at the discretion of corporate organizations, it does not make CSR a freely chosen programme to contribute towards social prosperity.

The apparent conflict between CSR and firm objectives was noticed quite early by Friedman (1976), who had declared that any effort to use corporate resources for purely altruistic purposes would constitute socialism. In fact, Friedman recommended that corporation law should be modified to discourage CSR (Waddock, 2006). And yet more than thirty years after Friedman made his declaration, CSR has become the norm. Surprisingly enough, empirical research has indicated positive, neutral and even negative impacts of CSR on financial performance. While CSR skeptics can explain away the practice of CSR as a result of pressure from society, an explanation for the profit motives behind CSR becomes even more necessary to explain the source of the social pressure. CSR of companies can be estimated in figures and included in financial statements of companies though there are different areas of focus.

\section{Types of Corporate Social Responsibility}

Carroll (1991) identified four focal areas of corporate social along the range of economic, legal, ethical and philanthropic responsibilities. 
European Journal of Business and Innovation Research

Vol.8, No.4.pp. 50-62, July 2020

Published by ECRTD-UK

Print ISSN: 2053-4019(Print), Online ISSN: 2053-4027(Online)

\section{Economic Responsibilities}

Historically, business organizations were created as economic entities designed to provide goods and services to societal members in order to generate profit. The profit motive was established as the primary incentive for entrepreneurship. Before it was anything else, the business organization was the basic economic unit in our society. As such, its principal role was to produce goods and services that consumers needed and wanted and to make an acceptable profit in the process. At some point the idea of the profit motive got transformed into a notion of maximum profits, and this has been an enduring value ever since. All other business responsibilities are predicated upon the economic responsibility of the firm (Carroll, 1991), because without it the others become moot considerations. However, economic responsibilities have to be achieved with reverence to the laws of the land where such business operates.

\section{Legal Responsibilities}

Society has not only sanctioned business to operate according to the profit motive; at the same time business is expected to comply with the laws and regulations promulgated by federal, state, and local governments as the ground ailes under which business must operate. As a partial fulfillment of the social contract between business and society, firms are expected to pursue their economic missions within the framework of the law. Legal responsibilities reflect a view of "codified ethics" in the sense that they embody basic notions of fair operations as established by our lawmakers. They are depicted as the second layer on the pyramid to portray their historical development (Carroll, 1991), but they are appropriately seen as coexisting with economic responsibilities as fundamental precepts of the free enterprise system.

\section{Ethical Responsibilities}

Although economic and legal responsibilities embody ethical norms about fairness and justice, ethical responsibilities embrace those activities and practices that are expected or prohibited by societal members even though they are not codified into law. Ethical responsibilities embody those standards, norms, or expectations that reflect a concern for what consumers, employees, shareholders, and the community regard as fair, just, or in keeping with the respect or protection of stakeholders' moral rights (Carroll, 1991). In one sense, changing ethics or values precede the establishment of law because they become the driving force behind the very creation of laws or regulations. For example, the environmental, civil rights, and consumer movements reflected basic alterations in societal values and thus may be seen as ethical bellwethers foreshadowing and resulting in the later legislation. In another sense, ethical responsibilities may be seen as embracing newly emerging values and norms society expects business to meet, even though such values and norms may reflect a higher standard of performance than that currently required by law. Ethical responsibilities in this sense are often ill-defined or continually under public debate as to their legitimacy, and thus are frequently difficult for business to deal with which makes it interesting for the study to focus on this. 
European Journal of Business and Innovation Research

Vol.8, No.4.pp. 50-62, July 2020

Published by ECRTD-UK

Print ISSN: 2053-4019(Print), Online ISSN: 2053-4027(Online)

\section{Philanthropic Responsibilities}

Philanthropy encompasses those corporate actions that are in response to society's expectation that businesses be good corporate citizens. This includes actively engaging in acts or programs to promote human welfare or goodwill. Examples of philanthropy include business contributions of financial resources or executive time, such as contributions to the arts, education, or the community. A loaned-executive program that provides leadership for a community's United Way campaign is one illustration of philanthropy. The distinguishing feature between philanthropic and ethical responsibilities is that the former are not expected in an ethical or moral sense. Communities desire firms to contribute their money, facilities, and employee time to humanitarian programs or purposes, but they do not regard the firms as unethical if they do not provide the desired level. Therefore, philanthropy is more discretionary or voluntary on the part of businesses even though there is always the societal expectation that businesses provide it. One notable reason for making the distinction between philanthropic and ethical responsibilities is that some firms feel they are being socially responsible if they are just good citizens in the community. This distinction brings home the vital point that CSR includes philanthropic contributions but is not limited to them. In fact, it would be argued here that philanthropy is highly desired and prized but actually less important than the other three categories of social responsibility.

\section{Firm's Performance}

The subject of firm's performance has received significant attention from scholars in the various areas of business and strategic management (Jat, 2006). It has also been the primary concern of business practitioners (managers and entrepreneurs in all types of organizations because corporate performance is essential as exemplified in high performance organizations which are success stories because of their perceived effectiveness and efficiency in managing their operations and their positive contributions to the well-being of their stakeholders. Whereas, low performance organizations are not, owing to their lack of such essential attributes (Jat, 2006).

Performance is however, a difficult concept, in terms of definition and measurement. It has been defined as the end result of activity, and the appropriate measure selected to assess corporate performance is considered to depend on the type of organization to be evaluated and the objectives to be achieved through that evaluation (Jat, 2006). According to Lin and Liu (2005) in business management, financial ratios are usually one of the indicators used to evaluate a firm's performance. Generally, the financial information of a company's business operations will be reported in the yearly financial statements, and a financial ratio simply constitutes one item divided by another in the financial statement. Financial ratios can be viewed as a preliminary reference for the analysis of the business performance. This agrees with Osisioma (1996:339) assertion that "ratios relate one set of values to another, with the resulting quotient serving as a measure, a standard or a norm by which performance is judged.

Financial performance is an indicator of the firm's attainment of economic or financial objectives. The long term survival and value of a firm is dependent on its ability to maintain desirable profit levels through its operating activities. Information regarding a firm's financial performance is obtained from the financial statements on which stakeholders base their decisions in terms of either investment or sustenance of contractual business relationships with the entity. According to 
European Journal of Business and Innovation Research

Vol.8, No.4.pp. 50-62, July 2020

Published by ECRTD-UK

Print ISSN: 2053-4019(Print), Online ISSN: 2053-4027(Online)

Rabi'u, Asma'u, Jamila, and Musa (2016), the American Institute of Certified Public Accountants (AICPA) are of the view that financial statements permit analysis of a wide range of trends and relationships among the data providing insight into a company's opportunities and risks, including growth, market acceptance, costs, productivity, profitability, liquidity amongst others. The most common measures of a firm's financial performance are categorized into Profitability and Market value measures which are of interest to both shareholders and stakeholders.

\section{Stakeholder's Theory (Freeman, 1984)}

Beyond its stockholders, a firm has a number of stakeholders. These include its employees, customers, suppliers, distributors, creditors, host communities and the government. The performance and success of the firm depends on how well it is able to manage its relationships with these stakeholders (Freeman, Wicks, \& Parmar, 2004). Indeed to succeed, managers need to harmonize the usually conflicting interests of these stakeholders. Where these interests are properly managed, the support of the stakeholders can be counted upon, while the firm is seen as a good platform upon which the stakeholders' interests can be maximized (Duke, Kankpang \& Okonkwo, 2012). This Stakeholder theory suggests that since people voluntarily associate in a firm, their interests must be pursued single-mindedly. Managers of firms can only secure their cooperation towards achieving organizational goals when they successfully develop quality relationships with these stakeholders. Generating this positive relationship will naturally include the provision of social projects and other actions that are normally costly for the firm, at least in the short run. Profits may then be the assured outcome of this association, once value is created (Freeman, Wicks, \& Parmar, 2004).

This study is anchored on the stakeholder theory of organization management and business ethics which deals with values and morals in managing an organization. This theory maintains that there is need for an organization to engage in active social role in the society where it is operating since it depends on the society for sustenance (Ojo, 2012). Investors, shareholders, employees, customers, suppliers, government and the communities are the stakeholders capable of influencing organizational performance of which managers must ensure that their demands are satisfied according to this theory. The stakeholder theory therefore takes into consideration the need to satisfy those interested parties capable of influencing organizational performance if an organization is to survive in its environment. CSR has become a necessity in this present time due to the goodwill it generates and for the fact that interdependence exist between the corporate firms and the environment where they are operating. The purpose of establishing an enterprise is value creation that involves producing goods and services that will satisfy the demands of the society which maximizes profit for the owner and contribute in solving societal needs (Akindele, 2011). Stakeholder theory, therefore, is concerned typically with how the organization manages its stakeholders. Thus the information disclosed to the stakeholders may be assumed more properly by the organization to be part of a legitimacy and/or social process.

Stakeholder theory is an extension of the agency view, which expects board of directors to take care of the interests of shareholders. However, this narrow focus on shareholders has undergone a change and boards are now expected to take into account the interests of many different stakeholder groups, including interests groups linked to social, environmental and ethical 
European Journal of Business and Innovation Research

Vol.8, No.4.pp. 50-62, July 2020

Published by ECRTD-UK

Print ISSN: 2053-4019(Print), Online ISSN: 2053-4027(Online)

considerations (Freeman, 1984; Donaldson \& Preston, 1995; Agle, Donaldson, Freeman, et al, 2008). This shift in the role of the boards has led to the development of stakeholder theory. Stakeholder theory views "companies and society as interdependent and therefore the firm serve a broader social purpose than its responsibilities to shareholders" (Kiel \& Nicholson, 2003:31). Likewise, Freeman (1984:46) defines stakeholder as "any group or individual who can affect or is affected by the achievement of the organization's objectives."

There is considerable debate among scholars on whether to take a broad or narrow view of a firm's stakeholder. Freeman's definition (1984) cited above proposes a broad view of stakeholders covering a large number of entities, and includes almost all types of stakeholders. In contrast, Clarkson (1994:5) offers a narrow view, suggesting "voluntary stakeholders bear some form of risk as a result of having invested some form of capital, human or financial, or something of value, in a firm. Involuntary stakeholders are placed at risk as a result of a firm's activities. But without the element of risk there is no stake." The use of risk enables stakeholders a legitimate claim on a firm's decision making, regardless of their power to influence the firm.

Freeman, Wicks, and Parmar, (2004) suggest that managers should try to create as much value for stakeholders as possible by resolving existing conflicts among them so that the stakeholders do not exit the deal. Carver and Oliver (2002:60) examine stakeholder view from non-financial outcomes. For example, while shareholders generally define value in financial terms, other stakeholders may seek benefits "such as the satisfaction of pioneering a particular breakthrough, supporting a particular kind of corporate behavior, or where the owner is also the operator, working in a particular way". It means stakeholders have 'non-equity stakes' which requires management to develop and maintain all stakeholder relationships, and not of just shareholders. This suggests the need for reassessing performance evaluation based on traditional measures of shareholder wealth and profits by including measures relating to different stakeholder groups who have nonequity stakes.

Nonetheless, many firms do strive to maximize shareholder value while, at the same time, trying to take into account the interest of the other stakeholders. Sundaram and Inkpen, (2004) argue that objective of shareholder value maximization matters because it is the only objective that leads to decisions that enhance outcomes for all stakeholders. They argue that identifying a myriad of stakeholders and their core values is an unrealistic task for managers (Sundaram \& Inkpen, 2004). Proponents of stakeholder perspective also argue that shareholder value maximization will lead to expropriation of value from non-shareholders to shareholders. However, Enuoh \& Enuoh (2018) posit that most firms are involved in CSR because of what they intend to benefit and not solely for the good of stakeholders. They posit that managers should develop relationships, inspire their stakeholders, and create communities where everyone strives to give their best to deliver the value the firm promises. Thus the stakeholder theory is considered to better equip managers to articulate and foster the shared purpose of their firm.

This theory emphasizes that the firm has a relationship with its stakeholders and the processes and outcomes of these relationships are of interest (Hillman and Luce, 2001). It purports that since businesses focus to appeal to both financial and non-financial stakeholders, they should focus on engaging in CSR undertakings that are apparently significant to non-financial stakeholder groups. 
European Journal of Business and Innovation Research

Vol.8, No.4.pp. 50-62, July 2020

Published by ECRTD-UK

Print ISSN: 2053-4019(Print), Online ISSN: 2053-4027(Online)

This is because the firm needs both of these groups to be sustainable in the long run. The stakeholder theory proposes that CSR is positively associated with corporate financial performance. Friedman (1970) identified stakeholders as customers, employees, local communities, suppliers and distributors as well as shareholders. Other groups and individuals are also considered stakeholders, including, the media, the public, business partners, future generations, past generations (founders of organizations), academics, competitors, NGOs or activists, stakeholder representatives such as trade unions or trade associations of suppliers or distributors, financiers other than stockholders (debt holders, bondholders and creditors), competitors and government, regulators and policymakers.

Stakeholder theory recognizes the long-term effect that the actions of stake holders may have on the company as their relationship will also enhance trade. Jensen (2002) proposes that the society expects the organization to perform various responsibilities in order for them to survive. Zingales (2000) also suggests that firms can only succeed by maintaining a quality relationship with the society. Freeman (1984) postulated that a firm possesses both formal and informal agreements with numerous stakeholders and are hence liable to honour all such contracts. This enables the company to develop its reputation. Implied contracts become self-regulating through maintaining this relationship and the cost associated with these contracts also reduces (Telser, 1980). Moreover, Tesler argued that it improves performance and reputation of the firm. The function of management is to balance the expectations of different existing stakeholders through their operating activities (Ansoff 1965).

\section{METHODOLOGY}

The study adopted expost-facto research design. Information was obtained from secondary sources of data. The study was conducted in manufacturing sector. The annual financial statements of Lafarge Holcim (Unicem Ltd) Calabar, from 2010 to 2016 was used. The annual accounts used for gathering data have been prepared in accordance with the relevant and prevailing regulatory and mandatory rules, standards and guidelines enforced by the Securities and Exchange Commission (SEC), Corporate Affairs Commission (CAC), Financial Reporting Council (FRC) etc. Reliability is shown by the fact using the same data and applying the same regulatory and mandatory standards, the same results shall be produced.

\section{Model specification and technique of data analysis}

A model represents simplified representation of real life situation (application). Specification is based on the available data to the subject of the study. The field data obtained was presented and analyzed using tables and percentages while the model adopted in analyzing the hypothesis generated through field work was

PREF $=\infty+\beta_{1} C W M+\beta_{2} C R A+\beta_{3} C S S+e$

Where;

PREF = Profitability

$\mathrm{CWM}=\quad$ Cost of Waste management 
European Journal of Business and Innovation Research

Vol.8, No.4.pp. 50-62, July 2020

Published by ECRTD-UK

Print ISSN: 2053-4019(Print), Online ISSN: 2053-4027(Online)

$\begin{array}{lll}\mathrm{CRA} & = & \text { Community Relations Activities } \\ \mathrm{CSS} & = & \text { Community Scholarship Scheme } \\ \infty & = & \text { intercept } \\ \mathrm{e} & = & \text { error } \\ \beta & = & \text { co- efficient } \\ \mathrm{B} \geq 0 & \end{array}$

The data collected will be analyzed using multiple regression.

DATA PRESENTATION AND ANALYSIS OF REGRESSION RESULTS

Regression result

Dependent variable: Profitability (PREF)

\begin{tabular}{lllll}
\hline VARIABLES & Coefficient & $\begin{array}{l}\text { Standard } \\
\text { error }\end{array}$ & t-statistics & probability \\
\hline Constant & 13.19931 & 2.095163 & 6.299895 & 0.0000 \\
CWM & -0.056202 & 0.081386 & -0.690561 & 0.4914 \\
CRA & 0.202982 & 0.094326 & 2.151907 & 0.0337
\end{tabular}

$\mathbf{R}^{2}=0.057758, \mathbf{R}^{2}$ adjusted $=0.039979, \mathbf{F}$-statistics $=3.248791, \mathbf{D W}=2.470573$, S.E. of regression $=2.081463$,Hannan-Quinn criter. $=4.361196$,S.D. dependent var $=2.124362$

$\operatorname{Prob}(\mathrm{F}$-statistic $)=0.022719, \mathbf{N}=109 ; *$ significant at .05 level

Source: Appendix - Data analysis results.

The regression result above shows the systematic relationship between the dependent variable Profitability (PREF) and the independent variables Cost of Waste Management (WM), C Community relations activities and Community Scholarship schemes.

The result shows that there is an inverse relationship between profitability and waste management although this relationship is not significant. .On the other hand, there is a direct relationship between profitability and Community Relations Activities (CRA) and Community Scholarship Schemes (CSS). Specifically, the relationship is such that if Community Relations Activities (CRA) or Community Scholarship Scheme increases by 1 unit, Profitability improves by 0.20 units or 0.02 units respectively. The constant term is also positive and highly significant. 
European Journal of Business and Innovation Research

Vol.8, No.4.pp. 50-62, July 2020

Published by ECRTD-UK

Print ISSN: 2053-4019(Print), Online ISSN: 2053-4027(Online)

\section{Econometric Analysis}

The coefficient of determination (R-squared) shows the explanatory power of the model. We use the adjusted component of the coefficient of determination to explain this because it accounts for degrees of freedom. The adjusted R-squared value of 0.039979 shows that the independent variables, Cost of Waste Management (CWM),Community Scholarship Scheme (CSS), Community Relations Activities (CRA) explain only about $29 \%$ of the systematic variations in profitability of Lafarge Holcim (Unicem) Calabar. This clearly indicates that the perception of the respondents is that Waste Management cost, Community Scholarship Scheme and Community Relations Activities do not provide very strong explanations for the systemic variations in the profitability of Lafarge Holcim (Unicem) Calabar and there may be other factors which can explain this better. The Durban Watson statistic of 2.47 hovers around 2 which is the conventional level and indicates the absence of severe serial correlation in the model, that is, the stochastic terms are not serially correlated.

The F-statistic of 3.25 with a P-value of 0.022 shows that the independent variables are jointly significant. The P-value falls in the rejection region of the null hypothesis which is below the significance level of 5\% (0.05), hence we reject the null hypothesis and accept the alternate hypothesis that says the independent variables have predictive effects on the dependent variable. This indicates that the model is able to properly predict the relationship between the variables.

\section{DISCUSSION OF FINDINGS}

The results clearly show that the cost of waste management which is part of ethical responsibilities of the firm has an inverse relationship with the profitability of Lafarge Holcim (Unicem). Although, this relationship is not significant, it at least shows that waste management constitutes a cost to the firm and thus reduces profitability, but this reduction is considered as normal business operating expenditure. This can only be reversed if the firm can adopt a good business model out of waste management that sees it re-cycle and re-use waste, save costs and even generate more revenue, this goes beyond the conventional waste management system to ensuring that the company's waste does not impact negatively in the community.

CSR as captured by Community Relations Activities (CRA) is seen to have a significant direct (positive) relationship with the financial performance of Lafarge Holcim (Unicem), Calabar as captured by its profitability. This finding is quite plausible as it shows that the involvement of Lafarge Holcim (Unicem), Calabar in CSR confers goodwill on the firm which ensures it continues to perform well as a firm. Lafarge Holcim (Unicem) commitment to Community Relations Activities may have created a good rapport between the firm and its operating environment which ensures it does business without any hindrance and this has reflected on the firm's financial performance over the years.

This study therefore concludes in the light of the results obtained from Lafarge Holcim (Unicem), Calabar that corporate social responsibility can impact on a firm's financial performance especially when it is appropriately targeted. The implication therefore for firms operating in the Nigerian harsh business environment is that they can improve financial performance by committing to welltargeted community relations activities geared towards reducing negative environmental 
European Journal of Business and Innovation Research

Vol.8, No.4.pp. 50-62, July 2020

Published by ECRTD-UK

Print ISSN: 2053-4019(Print), Online ISSN: 2053-4027(Online)

conditions. Though ethical responsibilities are often imprecise and in some cases under public debate as to their legitimacy, it is still considered as a core value of most firms because compliance contributes to environmental sustainability.

\section{CONCLUSION AND RECOMMENDATIONS}

The finding from this study shows clearly that corporate social responsibility of a firm can impact on its financial performance. Where a firm properly channels its CSR activities toward developing its environment, it gathers goodwill and this can result in future profit for the firm. Waste disposal strategies of these companies is so far viewed as a normal business operating expense, if such companies can channel more innovation into managing its waste. Though engaging in such ethical responsibilities would increase the operation costs, innovating systems such as waste recycling and waste re-use could turn disposal waste into revenue generating outlets.

The following recommendations are suggested based on the findings of this study.

1. Environmental concerns should be paramount in firm's activities and waste disposal system should be further developed and enhanced to exploit all revenue generation possibilities available to the firms

2. Firms should consolidate on their community relations activities such as scholarships, donations, community health care programs, skills acquisition programs etc. these enhances the image of the firm in the public view and this can translate to future profit and capital investment.

\section{REFERENCES}

Agle, B. R., Donaldson, T., Freeman, R. E., Jensen, M. C., Mitchell, R. K., \& Wood, D. J. (2008). Dialogue: Toward superior stakeholder theory. Business Ethics Quarterly, 18(2), 153-190.

Ansoff, H. I. (1965).Corporate strategy; an analytic approach to business policy for growth and expansion. New York, McGraw-Hill.

Akindele R. I. (2011). Corporate social responsibility: An organizational tool for survival in Nigeria www.readperiodicals.com.

Azende, T. (2013).Corporate social responsibility in Nigerian banking system: the development of small and medium scale enterprises.

Carver, J., \& Oliver, C. (2002).Corporate Boards that Create Value: Governing Company Performance from the Board Room. San Francisco, CA: Jossey - Bass, John Wiley.

Carroll, A. B. (1991). The Pyramid of Corporate Social Responsibility: Toward the Moral Management of Organizational Stakeholders. Business Horizons, 34(4), 39-48.

Clarkson, M. (1994). A risk based model of stakeholder theory. In Proceedings of the second Toronto conference on stakeholder theory (pp. 18-19).

Comincioli, N., Poddi, L., \&Vergalli, S. (2012). Corporate social responsibility and firms' performance: A stratigraphical analysis, FondazioneEni Enrico MatteiWorking Paper 77.

Donaldson, T., \& Preston, L. E. (1995). The Stakeholder Theory of the Corporation: Concepts, Evidence and Implications. Academy of Management Review, 20(1), 65-91. 
European Journal of Business and Innovation Research

Vol.8, No.4.pp. 50-62, July 2020

Published by ECRTD-UK

Print ISSN: 2053-4019(Print), Online ISSN: 2053-4027(Online)

Duke II, Kankpamg, K. J., \& Okonkwo, G. (2012). Corporate governance as a driver of organizational efficiency in courier service firms: Empirical findings from Nigeria, Interdisciplinary Journal of Research in Business, 1(11), 26- 38.

Dutta, P., \& Bose, S. (2008). Corporate environmental on the Internet in Bangladesh: An Exploratory Study. International Review of Research Papers, 4(3), 138-150.

European Commission (2001).Promoting a European framework for corporate social responsibility - Green Paper, Office for Official Publications of the European Communities, Luxembourg.

Enuoh, R.O. (2019). Business Ethics and the Nigerian Oil Industry: A Study of the Niger Delta. International Journal of Research and Innovation in Social Science (IJRISS) 9(7) 285-293.

Enuoh, R. O. \& Eneh, S. (2015). Corporate social responsibility in the Niger Delta Region of Nigeria: In who's interest? Journal of Management and Sustainability, 5(3), 74-84.

Enuoh, R.O. \& Enuoh, O. O. (2018). Corporate Social Responsibility and Social License to Operate: exploring activities of oil Multinationals in the Niger Delta region of Nigeria. Journal of Resources Development and Management, 51,1-11.

Freeman, R.E (1984). Strategic Management: A stakeholder Approach. Boston, MA: Pitman

Freeman, R. E. Wicks, A. C., \& Parmar, B. (2004). Stakeholder theory and the corporate objective revisited, Organization Science, 15(3), 364-369.

Friedman, M. (1976). “The Social Responsibility of Business Is to Increase its Profits." New York Times Magazine. 13 September: 122-126.

Friedman, M. (1970) The social responsibility of business is to increase its profits. New York times, 13 (32-33), 122-126.

Hillman A. J , \& Luce R. A. (2001). Board Composition and Stakeholder Performance: Do Stakeholder Directors Make a Difference?https://doi.org/10.1177/000765030104000304

Jat, R. B. (2006). The impact of market structure on corporate performance in Nigeria: A study of the banking industry.Journal of Business Management 1(1).14-38.

Jensen M. (2002).Value Maximization, Stakeholder Theory, and the Corporate Objective Function. Business Ethics Quarterly. 12(2); 235-256. DOI: 10.2307/3857812

Kiel, G. C. \& Nicholson, G. J. (2003).Board Composition and Corporate Performance: how the Australian experience informs contrasting theories of corporate governance. https://doi.org/10.1111/1467-8683.00318

Lin, W. \& Liu, C. (2005).Performance efficiency evaluation of the Taiwan's shipping industry: An application of data envelopment analysis, proceeding of the Eastern Asia Society for Transportation studies.

Ojo, O. (2012). Appraisal of the Practice of Social Responsibility by Business Organization in Nigeria. Retrieved from http:// www.google.com.ng

Osisioma, B. C. (1996). Analysis of financial statements, in Osisioma, B. C. (Ed.) Studies in accounting: Text and reading, revised and enlarged, (PP. 338-359), Enugu: Acena.

Rabi'u S. J.,Asma'u, Y. D., Jamila, M., \& Musa, B. (2016).Corporate Social Responsibility and Financial Performance of Quoted Deposit Money Banks in Nigeria.Research Journal of Finance and Accounting, 7(13), 40-48.

Sundaram, A. K., \& Inkpen, A. C. (2004). The Corporate Objective Revised. Organisation Science, 15(3), 350-363. 
European Journal of Business and Innovation Research

Vol.8, No.4.pp. 50-62, July 2020 Published by ECRTD-UK

Print ISSN: 2053-4019(Print), Online ISSN: 2053-4027(Online)

Telser, L. G. (1980). A Theory of Self-Enforcing Agreements.The Journal of Business.53(1); 2744.

Waddock, S. (2006).Building the Institutional Infrastructure for Corporate Social Responsibility, Corporate Social Responsibility Initiative, John F. Kennedy School of Government, Harvard University Working Paper 32.

Zingales L. (2000). In Search of New Foundations, Journal of Finance. 1623- 1653. 